\title{
JURNAL EKONOMI \\ EFEKTIF

\section{ANALISIS IMPLEMENTASI GLOBAL VISION MELALUI STRAREGI PEMASARAN PERUSAHAAN ROTI MAULANA BAKERY YANG BERIMPLIKASI PADA DAYA SAING}

\author{
${ }^{1}$ Darmadi, ${ }^{2}$ Rahmad Setiawan \\ dosen02445@unpam.ac.id
}

\begin{abstract}
ABSTRAK
Penelitian ini menganalisis pengimplementasian global vision melalui strategi pemasaran terhadap Perusahaan Roti Maulana Bakery. Penelitian ini menganalisis kesesuaian strategi pemasaran saat ini dengan implementasi pencapaian target perusahaan. Penelitian ini menganalisis pemetaan dan faktor penyebab pada lingkungan eksternal Perusahaan Roti Maulana Bakery.

Penelitian ini fokus mengkaji dan menganalisa penetapan opsi yang bisa direkomendasikan untuk mengimplementasikan global vision melalui strategi pemasaran yang lebih tepat guna menetapkan strategi yang lebih tepat bagi Perusahaan Roti Maulana Bakery. Metode yang digunakan dalam penelitian ini adalah metode analisis kualitatif yang dipadukan dengan metode deskriptif bentuk studi kasus pada Perusahaan Roti Maulana Bakery.

Hasil pembahasan analisis aspek internal (IFAS) dengan rincian yaitu indikator kekuatan (strength) sebesar 3,50 dikurangi dengan indicator kelemahan (weakness) yaitu -2,20 menghasilkan grand total sebesar 1,30. Dan hasil dari aspek eksternal (EFAS) dengan rincian yaitu indikator peluang (opportunity) sebesar 3,59 dikurangi dengan indikator ancaman (threath) yaitu $-2,28$ menghasilkan nilai grand total sebesar 1,31. Dari analisis yang telah dijelaskan di atas, dapat di gambarkan kondisi strategis perusahaan roti maulana bakery dalam sebuah grafik bahwa Perusahaan Roti Maulana Bakery berada pada posisi agresif pada matrik.Strategi pemasaran yang lebih tepat selain melihat analisis ancaman juga dengan menganalisis peluang dimana kreasi produk roti menjadi daya tarik konsumen dengan nilai 1,5 menunjukkan bahwa $42 \%$ indikator kreasi produk roti menjadi daya tarik konsumen berperan sangat penting menjadi peluang dalam peningkatan daya saing usaha roti. Minat dan daya beli konsumen akan produk roti yang tinggi dengan nilai 1,26 dimana 35\% indikator minat dan daya beli konsumen akan produk roti yang tinggi menjadi peluang besar pendorong pertumbuhan kemajuan perusahaan roti maulana bakery.
\end{abstract}

Kata kunci: Straregi Pemasaran, Strategi Daya Saing

\section{ABSTRACT}

This study analyzes the implementation of global vision through a marketing strategy for the Maulana Bakery Company. This study analyzes the appropriateness of the current marketing strategy with the implementation of achieving company targets. This study analyzes the mapping and causal factors in the external environment of the Roti Maulana Bakery Company. 
This research focuses on analyzing and analyzing options that can be recommended to implement global vision through more appropriate marketing strategies in order to determine more appropriate strategies for Roti Maulana Bakery Company. The method used in this research is a qualitative analysis method combined with a descriptive method of case study form at the Roti Maulana Bakery Company.

The results of the discussion of internal aspect analysis (IFAS) with details of an indicator of strength of 3.50 reduced by an indicator of weakness of -2.20 yield a grand total of 1.30. And the results from the external aspects (EFAS) with details of the opportunity indicator of 3.59 reduced by the threat indicator (threath) of -2.28 resulting in a grand total of 1.31. From the analysis described above, it can be described the strategic condition of the Maulana Bakery Bread Company in a graph that the Maulana Bakery Bread Company is in an aggressive position on the matrix. A more appropriate marketing strategy besides looking at threat analysis is also analyzing the opportunities where the creation of bakery products becomes the attractiveness of consumers with a value of 1.5 indicates that $42 \%$ of the indicator of the creation of bakery products becomes the main attraction of consumers having an important role as an opportunity to increase the competitiveness of the bread business. Consumer interest and purchasing power for high bread products with a value of 1.26 where $35 \%$ indicator of consumer interest and purchasing power for high bread products is a great opportunity to drive growth in the progress of the Maulana bakery company.

\section{Keywords: Marketing Structure, Competitiveness Strategy}

\section{PENDAHULUAN}

Di Indonesia usaha dibidang kuliner sangat diminati dan berkembang cukup pesat. Usaha kuliner merupakan usaha yang cukup menjanjikan karena untuk mendirikan usaha ini tidak memerlukan banyak modal dan pangsa pasarnya besar. Hal tersebut mendorong banyak orang untuk memulai bisnis dibidang kuliner. Peluang usaha dibidang kuliner khususnya roti belakangan ini cukup diminati dan berkembang. Pekembangan usaha roti sangat cepat dan semakin banyak variasi. Roti sudah menjadi bagian dari gaya hidup sebagian besar masyarakat di Indonesia. Hal ini dapat dilihat dari banyaknya industri usaha roti dengan skala besar, menengah serta kecil yang dibuka.

Di wilayah Tangerang khususnya Tangerang Kota, persaingan usaha roti cukup kompetitif. Beberapa perusahaan roti bahkan ada yang menampilkan desaign pemasaran yang menarik. Hal ini bertujuan untuk menarik minat konsumen serta keinginan menjadi leader market.

Maulana Bakery adalah satu dari sekian banyak perusahaan roti yang ada di Tangerang Kota. Maulana Bakery sendiri merupakan pecahan dari perusahaan roti pendahulunya yaitu Aprilia Bakery Ciledug. Rahmad Setiawan S.E merupakan pendiri perusahaan roti Maulana Bakery. Beliau merintis usaha roti ini sejak tahun 2007 berawal dari menjadi sales marketing di Aprilia Bakery sampai beliau mendirikan pabrik roti sendiri pada tahun 2013. Keberanian ini beliau ambil selain dari pengalaman menjadi sales marketing tetapi juga karena dorongan dari dosen - dosen beliau sewaktu menempuh pendidikan S1 manajemen di Universitas Pamulang. Roti yang di produksi adalah roti manis dengan berbagai varian rasa seperti sosis keju, coklat caramel, keju caramel, coklat keju, mesis keju, blubbery wijen, durian manis, stawbery crispy dan varian menu lainnya dengan harga yang terjangkau untuk kalangan pelajar. Perusahaan Roti Maulana Bakery memiliki pangsa pasar di kantin sekolah, kantin kampus dan koperasi pabrik. 
Undang- undang yang mengatur tentang pangan dan kesehatan tertuang dalam UU RI No.7 Tahun 1996 berdasarkan UU maka kondisi ideal usaha panganan harus memperhatikan kualitas produk yang dihasilkan baik dari segi pemilihan bahan baku, proses produksi sampai produk jadi siap konsumsi. Usaha panganan harus memperhatikan batas akhir konsumsi suatu produk sehingga perlunya pemberitahuan yang tertera di label kemasan tentang masa akhir konsumsi produk (explaired). Berdasarkan pengamatan langsung kondisi Perusahaan Roti Maulana Bakery masih belum memenuhi kualifikasi usaha panganan yang ideal karena terlihat pada kemasan roti masih belum terdapat label halal MUI dan belum tertera tanggal kadaluarsa produk. Dari segi produksi Perusahaan Roti Maulana Bakery terhambat pada keterbatasan modernisasi mesin yang dimiliki karena sebagian proses produksinya masih menggunakan manual seperti cetak adonan varian rasa dan pada saat pengemasan. Pangsa pasar saat ini masih terbatas kantin sekolah dan kampus dan beberapa koperasi pabrik yang berada didaerah tangerang. Hal ini yang menjadi belum meningkatnya penjualan yang signifikan pada Perusahaan Roti Maulana Bakery.

Menurut Kotler, Philip and Kevin Lane Keller (2016:18) ada 5 (lima) konsep pemasaran yang dapat dijadikan acuan dalam menentukan strategi perusahaan, yaitu: konsep produksi, konsep produk, konsep penjualan, konsep pemasaran dan konsep pemasaran berwawasan sosial.

Creswell, Jhon W. 2016 (2016:19), perencanaan strategis berwawasan pasar adalah proses manajerial untuk mengembangkan dan menjaga sasaran keahlian dan sumberdaya organisasi sesuai dengan peluang pasar yang terus berubah, yang bertujuan untuk membentuk dan menyempurnakan bisnis serta produk perusahaan supaya memenuhi sasaran, keuntungan dan pertumbuhan.

Menurut Kotler, Philip and Kevin Lane Keller (2016:53) bahwa strategi pemasaran adalah membentangkan pasar sasaran dan proporsi nilai yang akan ditawarkan, berdasarkan pada suatu analisis peluang pasar terbaik. Strategi pemasaranjuga menuntutpemahaman yang jelas tentang cara pemasaran bekerja.

Berdasarkan uraian latar belakang masalah diatas maka penelitian ini dilakukan dengan menetapkan judul: "Analisis Implementasi Global Vision Melalui Straregi Pemasaran Perusahaan Roti Maulana Bakery yang Berimplikasi pada Daya Saing."

\section{METODE PENELITIAN}

\section{A. Tempat dan Waktu Penelitian}

\section{Tempat Penelitian}

Penelitian dilakukan di Perusahaan Roti Maulana Bakery yang beralamat di jalan H.Djum 1 No. 39 Kelurahan Paninggilan Utara Ciledug Tangerang.

2. Waktu Penelitian

Penelitian ini dilakukan selama Juli-September 2019

\section{B. Studi Kasus Tunggal}

Menurut Creswell, Jhon W. (2016:30) bahwa fokus studi kasus adalah spesifikasi kasus dalam suatu kejadian baik itu yang mencakup individu, kelompok budaya, organisasi ataupun suatu potret kehidupan. Lebih lanjut Creswell mengemukakan beberapa karakteristik dari suatu studi kasus yaitu:

1. Mengidentifikasi "kasus" untuk suatu studi.

2. Kasus tersebut merupakan sebuah "sistem yang terikat" oleh waktu dan tempat.

3. Studi kasus menggunakan berbagai sumber informasi dalam pengumpulan datanya untuk memberikan gambaran secara terinci dan mendalam tentang respons dari suatu peristiwa. 
4. Dengan menggunakan pendekatan studi kasus, peneliti akan "menghabiskan waktu" dalam menggambarkan konteks atau setting untuk suatu kasus yang terjadi.

\section{Metode Pengolahan dan Analisis Data}

Teknik analisis data yang digunakan dalam penelitian kualitatif mencakup transkip hasil wawancara, reduksi data, analisis, interpretasi data dan triangulasi.

Metode yang digunakan dalam penelitian ini adalah metode analisis kualitatif yang dipadukan dengan metode deskriptif bentuk studi kasus pada Perusahaan Roti Maulana Bakery. Analisa data yang dilakukan penelitian adalah :

1. Analisis Kualitatif

Memilih analisis kualitatif, menggunakan beberapa bentuk pengumpulan data seperti transkrip wawancara terbuka dengan pihak-pihak yang berkompeten, deskripsi observasi, serta analisi dokumen dan artefak lainnya. Data tersebut dianalisis dengan tetap mempertahankan keaslian teks yang memaknainya. Hal ini dilakukan karena tujuan penelitian kualitatif adalah memahami fenomena dari sudut pandang partisipan, konteks sosial dan institusional. Sehingga pendekatan kualitatif umumnya bersifat induktif.

2. Analisis Deskriptif

Analisis ini bertujuan untuk memperoleh gambaran yang jelas tentang hal-hal yang berkaitan dengan objek penelitian. Hasil dan analisis ini disajikan dalam bentuk tulisan, tabulasi data, dan gambar yang sesuai dengan konteks penelitian.

3. Analisis Lingkungan Perusahaan

Analisis lingkungan perusahaan meliputi lingkungan eksternal dan internal perusahaan. Menurut Husein Umar (2002:220) matriks EFE digunakan untuk mengevaluasi faktor-faktor eksternal perusahaan. Data dan informasi yang dikumpulkan untuk analisis lingkungan eksternal mencakup lingkungan mikro dan lingkungan makro. Analisis lingkungan makro dilakukan untuk faktor-faktor luar dan terpisah yang dihadapi perusahaan yang dapat menjadi peluang dan ancamanbagi perusahaan yaitu :

a. Lingkungan Demografi, berkaitan dengan masalah populasi dan tingkat pertumbuhan penduduk.

b. Lingkungan Ekonomi, berkaitan dengan peningkatan pertumbuhan ekonomi, laju inflasi, tingkat pendapatan dan daya beli masyarakat.

c. Lingkungan alam, meliputi letak geografis, potensi perkebunan dan iklim.

d. Lingkungan Teknologi, berkaitan dengan perkembangan teknologi.

e. Lingkungan Politik dan Hukum, berkaitan dengan situasi politik.

f. Lingkungan Sosial dan Budaya, berkaitan dengan perubahan sosial dalam masyarakat.

Analisis lingkungan mikro dilakukan dengan melihat berbagai perilaku yang dekat dengan berkaitan langsung dengan perusahaan, di mana lingkungan tersebut dapat mempengaruhi kemampuan perusahaan dalam melayani pelanggannya. Para pelaku dalam lingkungan mikro yang diamati adalah :

a. Pemasok yang berkaitan dengan sistem pengadaan input, pemasok dan sistem pembelian.

b. Pelanggan, berkaitan dengan profil pelanggan yang dihadapi.

c. Pesaing, berkaitan dengan profil pesaing.

d. Analisis lingkungan internal menggunakan data dan informasi yang berasal dari aspek internal perusahaan, yang terbagi atas Produksi dan operasi, Sumber daya manusia dan karyawan, faktor keuangan, dan kompetensi pemasaran. 


\section{HASIL PENELITIAN DAN PEMBAHASAN}

1. Bagaimana mengimplementasikan global vision melalui strategi pemasaran terhadap Perusahaan Roti Maulana Bakery?

Strategi globalisasi dilakukan dengan scanning terhadap lingkungan; bisa melalui studi analisis pasar luar negeri untuk melihat peluang memperbesar bisnis ataupun merampingkan operasi. Kesalahan yang acap kali dilakukan dalam analisis globalisasi adalah mengaplikasikan model financial domestic tanpa memperhitungkan risiko institusional dari globalisasi. Perbedaan institusi dan risiko institusi akan memengaruhi proyeksi finansial kita. Institusi tersebut bisa formal, misalnya pemerintah, partai politik dan militer, serta bisa pula informal dalam wujud budaya. Perusahaan Roti Maulana Bakery dapat mengimplementasikan global vision melalui strategi pemasaran yang tepat yaitu dengan menganalisis terlebih dahulu kekuatan, kelemahan, peluang, dan ancaman. Dilihat dari kekuatan yang dimiliki perusahaan ini sudah menggunakan modernisasi alat produksi dan diimbangi modal usaha yang cukup besar. Kelemahannya terletak pada belum memiliki izin yang lengkap dari instasi terkait dalam hal ini label halal MUI. Peluang usaha roti cukup besar dilihat dari beralihnya jenis makanan yang di konsumsi dari nasi ke gandum (roti) dan pangsa pasar yang luas merupakan peluang terbaik untuk menjalankan usaha ini. Perusahaan Roti Maulana Bakery dapat memperluas pangsa pasarnya keluar negeri karena dilihat dari kekuatan dan peluang yang dimiliki. Walaupun pada fakta dilapangan perusahaan ini memiliki banyak pesaing dari perusahaan sejenis seperti sari roti, holland bakery dan lainnya.

2. Bagaimana membuat pemetaan analisis dan faktor penyebab pada lingkungan eksternal Perusahaan Roti Maulana Bakery?

Posisi Kondisi Daya Saing Perusahaan Roti Maulana Bakery

\section{1) Skoring Data IFAS}

Tabel 3.1 Tabel IFAS

\begin{tabular}{|c|c|c|c|c|}
\hline No & Lingkungan Internal & Bobot & Rating & Nilai \\
\hline \multicolumn{5}{|c|}{ Kekuatan } \\
\hline 1 & $\begin{array}{l}\text { Kualitas produk dan harga } \\
\text { terjangkau }\end{array}$ & 0,30 & 3,7 & 1,11 \\
\hline 2 & $\begin{array}{l}\text { Ketersediaan modal untuk } \\
\text { aktivitas dan produktifitas } \\
\text { perusahaan }\end{array}$ & 0,25 & 3,2 & 0,80 \\
\hline 3 & Varian rasa pada produk & 0,35 & 3,6 & 1,26 \\
\hline 4 & $\begin{array}{c}\text { Lingkungan perusahaan yang } \\
\text { bersih, luas dan asri }\end{array}$ & 0,10 & 3,3 & 0,33 \\
\hline \multicolumn{2}{|r|}{ Sub total 1} & 1 & & 3,50 \\
\hline \multicolumn{5}{|c|}{ Kelemahan } \\
\hline 1 & $\begin{array}{c}\text { Kecukupan dan kualitas SDM } \\
\text { belum maksimal }\end{array}$ & $-0,30$ & 2,1 & $-0,63$ \\
\hline 2 & $\begin{array}{c}\text { Kurangnya kelengkapan legalitas } \\
\text { usaha seperti label halal MUI }\end{array}$ & $-0,35$ & 2,8 & $-0,98$ \\
\hline 3 & $\begin{array}{c}\text { Kegiatan promosi dan pemasaran } \\
\text { belum maksimal }\end{array}$ & $-0,25$ & 1,6 & $-0,40$ \\
\hline
\end{tabular}




\begin{tabular}{|c|c|c|c|c|}
\hline 4 & $\begin{array}{c}\text { Fasilitas pabrik belum } \\
\text { termaintenance dengan baik }\end{array}$ & $-0,10$ & 1,9 & $-0,19$ \\
\hline Sub total 2 & 1 & & $-2,20$ \\
\hline Graand Total & \multicolumn{2}{|c|}{1,30} \\
\hline
\end{tabular}

\section{2) Skoring Data EFAS}

Tabel 1.2 EFAS

\begin{tabular}{|c|c|c|c|c|}
\hline No & Lingkungan Eksternal & Bobot & Rating & Nilai \\
\hline & Peluang & & & \\
\hline 1 & $\begin{array}{l}\text { Kreasi produk roti menjadi daya } \\
\text { tarik konsumen }\end{array}$ & 0,30 & 3,5 & 1,05 \\
\hline 2 & $\begin{array}{l}\text { Pangsa pasar yang luas menjadi } \\
\text { bagian penting peningkatan kuantitas } \\
\text { produksi }\end{array}$ & 0,25 & 3,7 & 0,95 \\
\hline 3 & $\begin{array}{l}\text { Minat dan daya beli konsumen akan } \\
\text { produk roti yang tinggi }\end{array}$ & 0,35 & 3,6 & 1,26 \\
\hline 4 & $\begin{array}{l}\text { Peningkatan pemanfaatan teknologi } \\
\text { dalam pembelian online oleh } \\
\text { konsumen }\end{array}$ & 0,10 & 3,3 & 0,33 \\
\hline \multicolumn{2}{|c|}{ Sub total 1} & 1 & & 3,59 \\
\hline \multirow[b]{2}{*}{1} & Ancaman & & & \\
\hline & $\begin{array}{l}\text { Perkembangan mutu perusahaan } \\
\text { pesaing }\end{array}$ & $-0,30$ & 2,3 & $-0,69$ \\
\hline 2 & $\begin{array}{l}\text { Perkembangan program pemasaran } \\
\text { perusahaan pesaing }\end{array}$ & $-0,25$ & 2,6 & $-0,65$ \\
\hline 3 & $\begin{array}{l}\text { Peningkatan teknologi perusahaan } \\
\text { pesaing }\end{array}$ & $-0,35$ & 2,2 & $-0,77$ \\
\hline 4 & $\begin{array}{l}\text { Kebijakan pemerintah akan izin edar } \\
\text { pangan dan legalitas usaha }\end{array}$ & $-0,10$ & 1,7 & $-0,17$ \\
\hline \multicolumn{2}{|r|}{ Sub total 2} & 1 & & $-2,28$ \\
\hline \multicolumn{2}{|r|}{ Grand Total } & \multicolumn{3}{|c|}{1,31} \\
\hline
\end{tabular}

Berdasarkan hasil scoring, dapat diketahui analisis IFAS dan EFAS sebagai berikut:

1. Lingkungan Internal

a. Faktor Kekuatan

Berdasarkan hasil scoring analisa, dapat diketahui bahwa aspek internal untuk indikator kekuatan (strength) yaitu mendapatkan total skor sebesar 3,50 dengan rincian terdiri dari beberapa indikator yaitu kualitas produk dan harga terjangkau $(1,11)$, ketersediaan modal untuk aktivitas dan produktifitas perusahaan $(0,80)$, Varian rasa pada produk $(1,26)$, Lingkungan perusahaan yang bersih, luas dan asri $(0,33)$.

Dalam hal aspek internal untuk indikator kekuatan (strength) dengan nilai sub total 3,50 didapatkan dua urutan besar yaitu (1) Varian rasa pada produk dengan nilai 1,26 menunjukan bahwa sekitar 36\% indikator varian rasa pada produk berperan sangat penting pada peningkatan daya saing usaha roti. (2) kualitas produk dan harga 
terjangkau dengan nilai 1,11 menunjukan bahwa sekitar 32\% unsur kualitas produk dan harga terjangkau dipersepsikan sebagai daya pendorong pertumbuhan kemajuan usaha roti. Dua aspek tersebut menjadi dominan kekuatan, artinya kedua aspek tersebut sangat mempengaruhi peningkatan daya saing di Perusahaan Roti Maulana Bakery.

b. Faktor Kelemahan

Berdasarkan hasil scoring, dapat diketahui bahwa aspek internal untuk indikator kelemahan (weakness) yaitu mendapatkan total skor sebesar -2,20 dengan rincian terdiri dari beberapa indikator yaitu Kecukupan dan kualitas SDM belum maksimal (0,63), Kurangnya kelengkapan legalitas usaha baik seperti label halal MUI (0,98),Kegiatan promosi dan pemasaran belum maksimal $(-0,40)$,Fasilitas pabrik belum termaintenance dengan baik $(-0,19)$.

Dalam hal aspek internal untuk indikator kelemahan (weakness) dengan nilai subtotal-2,20 didapatkan dua urutan besar yaitu (1) Kurangnya kelengkapan legalitas usaha seperti label halal MUI dengan nilai -0,98 menunjukan bahwa sekitar $22 \%$ unsur kurangnya kelengkapan legalitas usaha seperti label halal MUI dipersepsikan sebagai variabel yang sangat berpengaruh, hal ini berkenaan .(2) kecukupan dan kualitas SDM belum maksimal dengan nilai -0,63 menunjukan 29\% unsur kecukupan dan kualitas SDM belum maksimal sehingga menjadi penghambat aktivitas pertumbuhan perusahaan.

2. Lingkungan Eksternal

a. Faktor Peluang

Berdasarkan hasil scoring analisa SWOT, dapat diketahui bahwa aspek eksternal untuk indikator peluang (opportunity) yaitu mendapatkan total skor sebesar 3,59 dengan rincian terdiri dari beberapa indikator yaitu Kreasi produk roti menjadi daya tarik konsumen(1,5), Pangsa pasar yang luas menjadi bagian penting peningkatan kuantitas produksi $(0,9)$, Minat dan daya beli konsumen akan produk roti yang tinggi $(1,26)$, Peningkatan pemanfaatan teknologi dalam pembelian online oleh konsumen $(0,33)$.

Dalam hal aspek ekternal untuk indikator peluang (opportunity) dengan sub total 3,59 didapatkan dua urutan besar yaitu (1) kreasi produk roti menjadi daya tarik konsumen dengan nilai 1,5 menunjukkan bahwa 42\% indikator kreasi produk roti menjadi daya tarik konsumen berperan sangat penting menjadi peluang dalam peningkatan daya saing usaha roti. (2) Minat dan daya beli konsumen akan produk roti yang tinggi dengan nilai 1,26 dimana 35\% indikator minat dan daya beli konsumen akan produk roti yang tinggi menjadi peluang besar pendorong pertumbuhan kemajuan perusahaan roti maulana bakery.

b. Faktor Ancaman

Berdasarkan hasil scoring analisis, dapat diketahui bahwa aspek eksternal untuk indikator ancaman (threat) yaitu mendapatkan total skor sebesar -2,28 dengan rincian terdiri dari beberapa indikator yaitu Perkembngan mutu perusahaan pesaing $(-0,69)$, Perkembangan program pemasaran perusahaan pesaing $(-0,65)$, Peningkatan teknologi perusahaan pesaing $(-0,77)$, Kebijakan pemerintah akan izin edar pangan dan legalitas usaha $(-0,17)$. Dalam hal aspek ekternal untuk indikator ancaman (threat) dengan sub total $-2,28$ didapatkan dua urutan besar yaitu (1) peningkatan teknologi perusahaan pesaing dengan nilai $-0,77$ atau sekitar $34 \%$ indikator peningkatan teknologi perusahaan pesaing menjadi ancaman bagi perusahaan roti maulana bakery.(2) Perkembangan mutu perusahaan pesaing dengan nilai -0,69 menunjukkan 
bahwa $30 \%$ indikator perkembangan mutu perusahaan pesaing menjadi pertimbangan cukup serius ancaman bagi perusahaan roti maulana bakery.

Maka dari analisis di atas, dari aspek internal (IFAS) dengan rincian yaitu indikator kekuatan (strength) sebesar 3,50 dikurangi dengan indicator kelemahan (weakness) yaitu -2,20 menghasilkan grand total sebesar 1,30. Dan hasil dari aspek eksternal (EFAS) dengan rincian yaitu indikator peluang (opportunity) sebesar 3,59 dikurangi dengan indikator ancaman (threath) yaitu -2,28 menghasilkan nilai grand total sebesar 1,31

Dari analisis yang telah dijelaskan di atas, dapat di gambarkan kondisi strategis perusahaan roti maulana bakery dalam sebuah grafik di bawah ini.

\section{Opportunity}

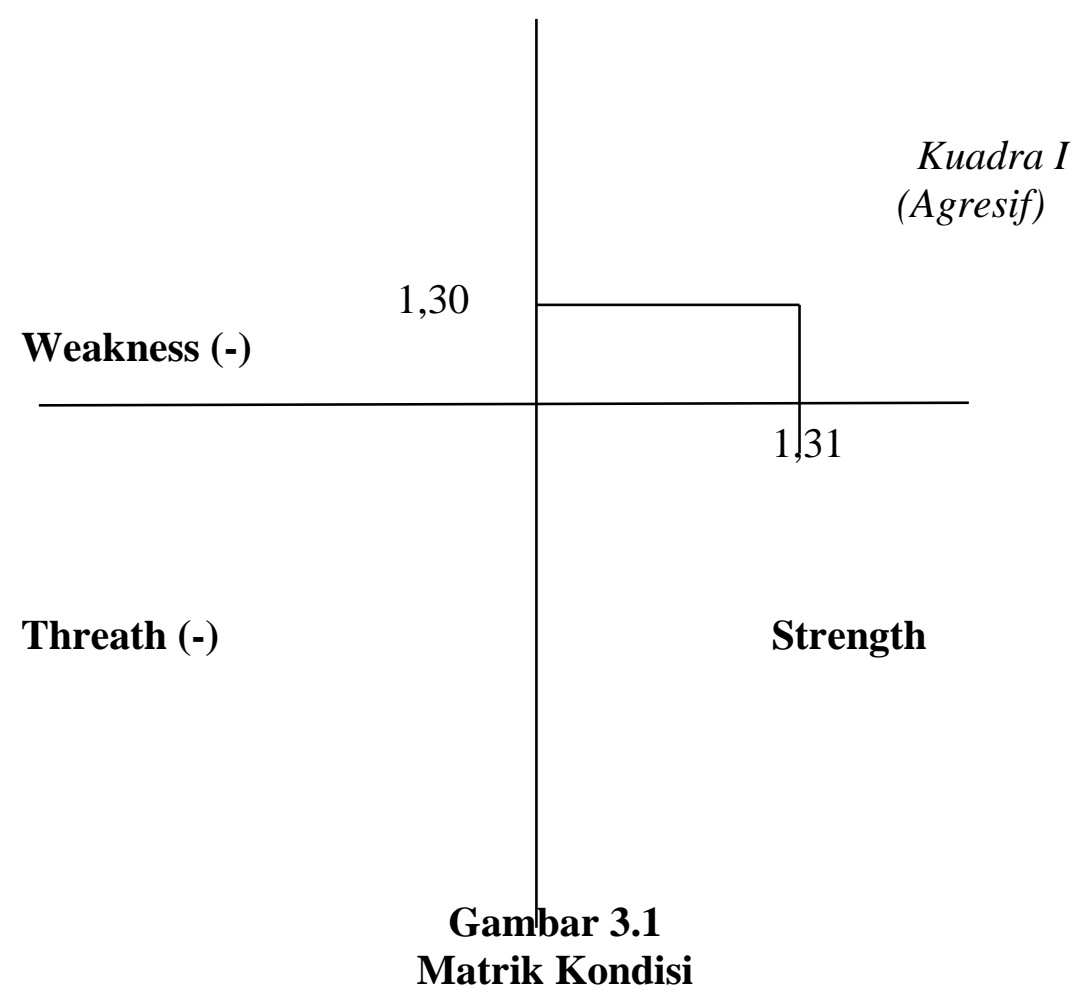

Berdasarkan pada grafik di atas, dapat diperoleh gambaran bahwa Perusahaan Roti Maulana Bakery berada pada posisi agresif pada matrik. Menurut Ranjabar, Jacobus.2013., ketika arah vector terletak di kuadran agresif, berarti perusahaan tersebut berada pada kondisi sangat bagus untuk memanfaatkan kekuatan internalnya untuk (1) menarik keuntungan dari peluang eksternal, (2) mengatasi kelemahan internal dan (3) menghindari beragam ancaman eksternal. Oleh karenanya strategi pengembangan produk, integrasi ke belakang, integrasi horizontal, integrasi ke depan, diversifikasi atau kombinasi semuanya menjadi pilihan yang dapat di pertimbangkan. Dari posisi agresif di atas, maka selanjutnya dapat dipergunakan masukan di dalam melakukan analisis SWOT.

c. Bagaimana penetapan opsi yang bisa direkomendasikan untuk mengimplementasikan global vision melalui strategi pemasaran yang lebih tepat dalam upaya meningkatkan daya saing Perusahaan Roti Maulana Bakery secara signifikan?

Meminimalisir kelemahan - kelemahan yang masih dimiliki Perusahaan Roti Maulana Bakery sehingga perusahaan ini dapat mewujudkan global visionnya. Hal lain adalah menduplikasi apa saja yang sudah menjadi kekuatan pesaing dalam hal ini 
adalah strategi pemasaran yang dijalankan pesaing. Peningkatan teknologi perusahaan pesaing dengan nilai $-0,77$ atau sekitar $34 \%$ indikator peningkatan teknologi perusahaan pesaing menjadi ancaman bagi perusahaan roti maulana bakery. Perkembangan mutu perusahaan pesaing dengan nilai -0,69 menunjukkan bahwa $30 \%$ indikator perkembangan mutu perusahaan pesaing menjadi pertimbangan cukup serius ancaman bagi perusahaan roti maulana bakery. Strategi pemasaran yang lebih tepat selain melihat analisis ancaman juga dengan menganalisis peluang dimana kreasi produk roti menjadi daya tarik konsumen dengan nilai 1,5 menunjukkan bahwa $42 \%$ indikator kreasi produk roti menjadi daya tarik konsumen berperan sangat penting menjadi peluang dalam peningkatan daya saing usaha roti. Minat dan daya beli konsumen akan produk roti yang tinggi dengan nilai 1,26 dimana 35\% indikator minat dan daya beli konsumen akan produk roti yang tinggi menjadi peluang besar pendorong pertumbuhan kemajuan perusahaan roti maulana bakery.

\section{PENUTUP}

\section{A. Kesimpulan}

Kesimpulan atas masalah penelitian didasarkan atas temuan permasalahan penelitian yang teridentifikasi dan tersusun pada Bab I. Dimana tujuan dari penelitian ini adalah mencari jawaban atas rumusan masalah yang diajukan dalam penelitian ini. Hasil dari temuan penelitian ini diantaranya :

1. Strategi globalisasi dilakukan dengan scanning terhadap lingkungan, bisa melalui studi analisis pasar luar negeri untuk melihat peluang memperbesar bisnis ataupun merampingkan operasi. Perusahaan Roti Maulana Bakery dapat mengimplementasikan global vision melalui strategi pemasaran yang tepat yaitu dengan menganalisis terlebih dahulu kekuatan, kelemahan, peluang, dan ancaman. Dilihat dari kekuatan yang dimiliki perusahaan ini sudah menggunakan modernisasi alat produksi dan diimbangi modal usaha yang cukup besar. Peluang usaha roti cukup besar dilihat dari beralihnya jenis makanan yang di konsumsi dari nasi ke gandum (roti) dan pangsa pasar yang luas merupakan peluang terbaik untuk menjalankan usaha ini.

2. Faktor penyebab pada lingkungan eksternal analisis Perusahaan Roti Maulana Bakery terdiri dari persoalan ekonomi, sosial, budaya, demografi, politik dan hukum, teknologi serta data eksternal relevan lainnya. Maka dari analisis di atas, dari aspek internal (IFAS) dengan rincian yaitu indikator kekuatan (strength) sebesar 3,50 dikurangi dengan indicator kelemahan (weakness) yaitu -2,20 menghasilkan grand total sebesar 1,30. Dan hasil dari aspek eksternal (EFAS) dengan rincian yaitu indikator peluang (opportunity) sebesar 3,59 dikurangi dengan indikator ancaman (threath) yaitu -2,28 menghasilkan nilai grand total sebesar 1,31.

3. Meminimalisir kelemahan - kelemahan yang masih dimiliki Perusahaan Roti Maulana Bakery sehingga perusahaan ini dapat mewujudkan global visionnya. Hal lain adalah menduplikasi apa saja yang sudah menjadi kekuatan pesaing dalam hal ini adalah strategi pemasaran yang dijalankan pesaing. Strategi pemasaran yang lebih tepat selain melihat analisis ancaman juga dengan menganalisis peluang dimana kreasi produk roti menjadi daya tarik konsumen dengan nilai 1,5 menunjukkan bahwa $42 \%$ indikator kreasi produk roti menjadi daya tarik konsumen berperan sangat penting menjadi peluang dalam peningkatan daya saing usaha roti. Minat dan daya beli konsumen akan produk roti yang tinggi dengan nilai 1,26 dimana 35\% indikator minat dan daya beli konsumen akan produk roti yang tinggi menjadi peluang besar pendorong pertumbuhan kemajuan perusahaan roti maulana bakery. 


\section{B. Saran}

Berdasarkan Hasil Penelitian dan kesimpulan di atas, maka penulis mengajukan beberapa saran pada Perusahaan Roti Maulana Bakery:

1. Perusahaan Roti Maulana Bakery lebih inovasi dalam membuat roti dengan desaign pemasaran yang menarik.

2. Perusahaan Roti Maulana Bakery harus memperhatikan batas akhir konsumsi suatu produk sehingga perlunya pemberitahuan yang tertera di label kemasan tentang masa akhir konsumsi produk (explaired).

3. Roti Maulana Bakery sebaiknya segera melengkapi izin legalitas usaha untuk memenuhi kualifikasi usaha panganan yang ideal.

\section{DAFTAR PUSTAKA}

Creswell, Jhon W. 2016. Research Design Pendekatan Kualitatif, Kuantitatif, dan Mixed.

Yogyakarta: Pustaka Pelajar

Husein Umar. 2002. "Metode Penelitian untuk Skripsi dan Tesis Bisnis".

https://swa.co.id/swa/review/book-review/tools-untuk-melakukan-ekspansi-global

Ranjabar, Jacobus.2013. Sistem Sosial Budaya Indonesia. Bandung : Alfabeta.

Kotler, Philip and Kevin Lane Keller, 2016. Marketing Managemen, 15th Edition, Pearson

Education,Inc. 